\section{Nuclear power yes, Chernobyl reactor technology no}

\section{London}

A YEAR after the Chernobyl disaster, the Soviet Union remains firmly committed to nuclear power, both for electrical energy and district heating. But the RBMK channel-type uranium--graphite reactor, the type used at Chernobyl, seems to be on its way out. During the past two weeks, Soviet officials have indicated that the "RBMK technology is outdated" and will not be used for further power stations after eight now under construction are completed. Furthermore, according to the Swedish daily Upsala Nya Tidning, Evgenii Larin, an official at the Soviet Ministry of Nuclear Energy, has stated that the fourth reactor at Ignalina, an RBMK-based power station in eastern Lithuania, will now not be completed.

Since Chernobyl, both Sweden and Finland have been worried about the proximity of the RBMK stations at Ignalina and Leningrad; indeed, the Finnish government at one point made overtures to Moscow, suggesting that Finland would be willing to bear the cost of constructing Western-type containment buildings at the two sites, arguing that even if as the Soviets claim such structures are, objectively, unnecessary, they would be worth the expense to reassure the Finnish public.

Ignalina is situated in the Lithuanian lake district, an area of considerable agricultural and recreational importance. Last summer, shortly after the Chernobyl disaster, a former environment official at Ignalina, Dr Kazys Eringis, who now lives in the United States, warned that sloppy construction and operating techniques prevalent at the station could mean the emission of significant radioactive contaminants and, in the case of an accident, could render the whole of Lithuania, Latvia and Byelorussia uninhabitable. Lithuanian sources indicate that there has been considerable opposition to the expansion of Ignalina, not least because (as with a similar anti-nuclear movement in Soviet Armenia) the republic already has ample supplies of electrical energy for its own need, and the further expansion of the nuclear programme is simply to 'export' energy to other parts of the Soviet Union.

According to Dr Valerii Legasov, the Deputy Director of the Kurchatov Nuclear Power Institute in Moscow, and the chief Soviet spokesman at the Postaccident Review meeting on Chernobyl in Vienna last August, Soviet plans have long envisaged the phasing out of the RBMK, in favour of the safer and more modern water-water reactor, as soon as the giant nuclear equipment enterprise
Atommash could supply the necessary machinery. Atommash, however, was the focus of a major scandal four years ago, when a trouble-shooter from Moscow had to be sent to sort out inefficiency and corruption, and, according to Legasov, only the first stage of the plant is operating.

With the phasing out of the RBMK, the Soviet energy programme will be committed, in the short term, to the VVER, although long-term hopes and research programmes are focused on fast breeders (two are already in operation) and, eventually, on fusion power. Meanwhile the official view is that Chernobyl was the result of a breakdown of "work discipline", which led to unauthorized experiments with the reactor and more efficient training programmes, stricter operating rules and the modification of equipment to make unauthorized tampering physically impossible will be enough to guarantee safety.

Nevertheless, some experiments with power stations still continue within the socialist bloc. Izvestiya recently reported experiments at the Dukovany power station in Czechoslovakia in which the hydraulic tests on the reactor and the circulatory flushing of the primary circuit during the tuning and start-up operations were carried out simultaneously instead of, as previously, successively. The new procedure was said to have the approval of top-level experts, and to be not only faster (a saving of 66 days was reported) but also safer. This may well be so, but in the aftermath of Chernobyl any reports of reactor experiments, however highly approved, will undoubtedly arouse some public anxieties.

Vera Rich

\section{UK upland grazing still contaminated}

\section{London}

A YEAR after Chernobyl, tests are still under way to determine levels of caesium contamination in sheep in northern England and Wales, as government restrictions on the movement and slaughter of the animals remain in force. Initial mathematical model predictions of a quick decline in caesium levels proved incorrect because they failed to consider the special soil conditions in the uplands; the acidic peat soils with low clay content do not bind the caesium, which enters plant tissue to be consumed by the sheep. Over 270,000 sheep, plus their lambs, are under restrictions, compared to $\mathbf{4 . 2}$ million initially.

The British government has so far paid out $£ 4.3$ million in compensation to 7,500 farmers. As the radioactivity persists, officials have not yet been able to tell farmers when the restrictions on their live-stock might be lifted, or even whether next year's lambs will be free from contamination. Live monitoring techniques have shown ten per cent of the restricted animals tested since January have caesium levels over 1,000 becquerels per kilogram, the EEC-agreed limited for foodstuffs which is far more stringent than the preChernobyl limit recommended by the National Radiological Protection Board of 9,000 becquerels per kilogram.

Researchers at Bristol University are assessing radionuclide levels in grass and soil samples from uplands areas, by creating spring-like conditions to promote plant growth. The movement of caesium from the soil to plants and animals is being studied by the Institute for Terrestrial Ecology, which is aiming to establish the characteristics of areas that can absorb contamination.

Kathy Johnston

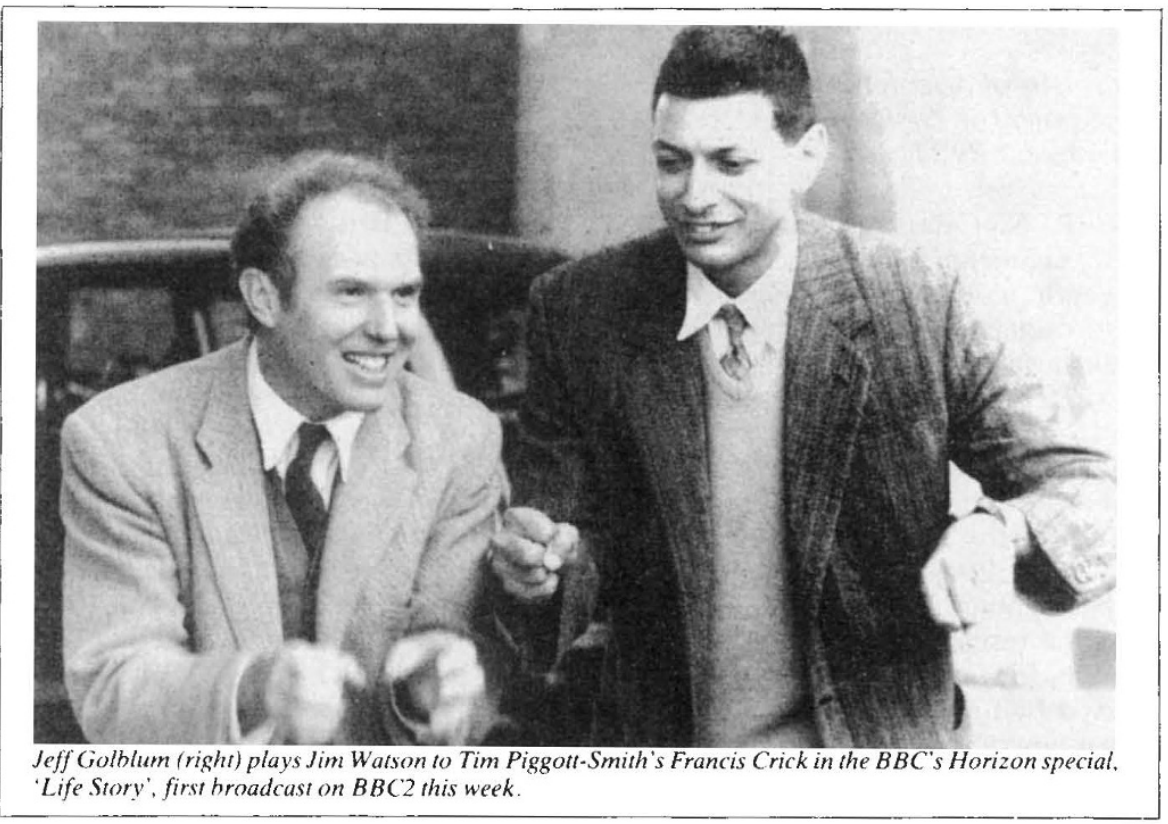

